\title{
MATHEMATICAL MODEL STUDIES FOR FLOOD PROTECTION MEASURES OF RIVER SWAN, HIMACHAL PRADESH
}

\author{
B. Raghuram Singh ${ }^{1}$, R. G. Patil ${ }^{2}$ \\ ${ }^{1}$ Scientist-B, Central Water \& Power Research Station (CWPRS), Pune-411024 \\ banothuraghu@yahoo.com \\ ${ }^{2}$ Scientist-D, Central Water \& Power Research Station (CWPRS), Pune-411024 \\ rsrgp@rediffmail.com
}

\begin{abstract}
:
Floods and flash floods are common water related natural disasters in the state of Himachal Pradesh. The flooding mostly occurs in summer season due to snow melt in the upper regions and coupled with heavy rainfall leads to heavy flooding in the lower regions. The other form of flooding is flash flood, which principally occurs due to cloud burst in the catchment area. The duration of flash flood is short but the damage caused by it is extensive. In Himachal Pradesh, the agriculture is practiced mostly on the flood plains of rivers. During flood, water spreads over the flood plains and causes damage to the agricultural fields. The river Swan experiences this kind of flooding every year. To protect the precious agricultural lands adjacent to the River Swan, IPH Department of HP proposed to construct flood protection measures along the banks of River Swan in the form of levees. One dimensional mathematical model HEC-RAS was used to study the location, alignment and various design parameters of the proposed embankments. The top level of the embankments were decided using the predicted maximum water levels with suitable free board. Based on the velocity of the flow computed, suitable protection measures were also suggested along with geo-fabric filter. Based on the model studies, adequately planned, well aligned and properly designed embankments have been recommended for Swan river.
\end{abstract}

Keywords: water level; flood embankment; velocity; free board.

\section{INTRODUCTION}

Floods are very common in the state of Himachal Pradesh. The state has experienced several floods for the last 4 decades. The flood disasters were very high in 1975 and 1988. The five major flood during the year 1997-2005 had high magnitude and frequency ( Sharma. D. D, 2006).

The major causes that are responsible for floods and flashfloods in the state are as below:-

1. Cloudburst in the catchment area of rivers.

2. Intensity of rainfall is very high in the upper reaches of rivers

3. Breaching or bursting of check dams or natural lakes.

4. Change in the river course due to landslides

5. Slope failure and landslides occurs due to tectonic movement of water (e.g. earthquake, Jan.1975).

During flood almost all the rivers of this state are passing a heavy discharge into them. floods in this state causes huge economic loss in the form of damage to not only crops, houses, public utilities, properties but also lost many human lives and cattle's. the magnitude and intensity of flood is varying from one basin to another.

The objective of flood control study is to decide which of the above works are most suitable, and their location, size, design and costs. Associated with this is an economic study to determine the potential damages averted by the projected works, and whether the benefits justify the cost. Flood control is a measure of protection for those threatened by floods against a future "maximum probable flood". In present state of our knowledge, no exact quantitative value can, however, be assigned to this entity, but there are various methods of approximating it. Using this probable flood data, one can design works either for this particular flood or for a lesser one, determined as a result of economic studies.



Fig.1: Index map of River Swan from Daulatpur bridge to Gagret bridge $(11 \mathrm{~km})$ 
River Swan (sorrow of Una district) originates near Daulatpur chawk in Amb district, flows through the intermountainous valley of Una district for a length of $85 \mathrm{~km}$ and meets River Sutlej near Anandpur Sahib in Punjab. Total catchment area of River Swan is about 1400 sq.km., out of which nearly 1200 sq.km., is in Himachal Pradesh and the remaining is in Punjab. Total 60 tributaries are joining river Swan in this $85 \mathrm{~km}$ reach. Due to the significant contribution of discharge from these tributaries, the river discharge continuously increases along the length while the longitudinal slope of the river reduces and becomes flatter. The combined effect of the two is the increase in width from its source to its confluence with river Sutlej.

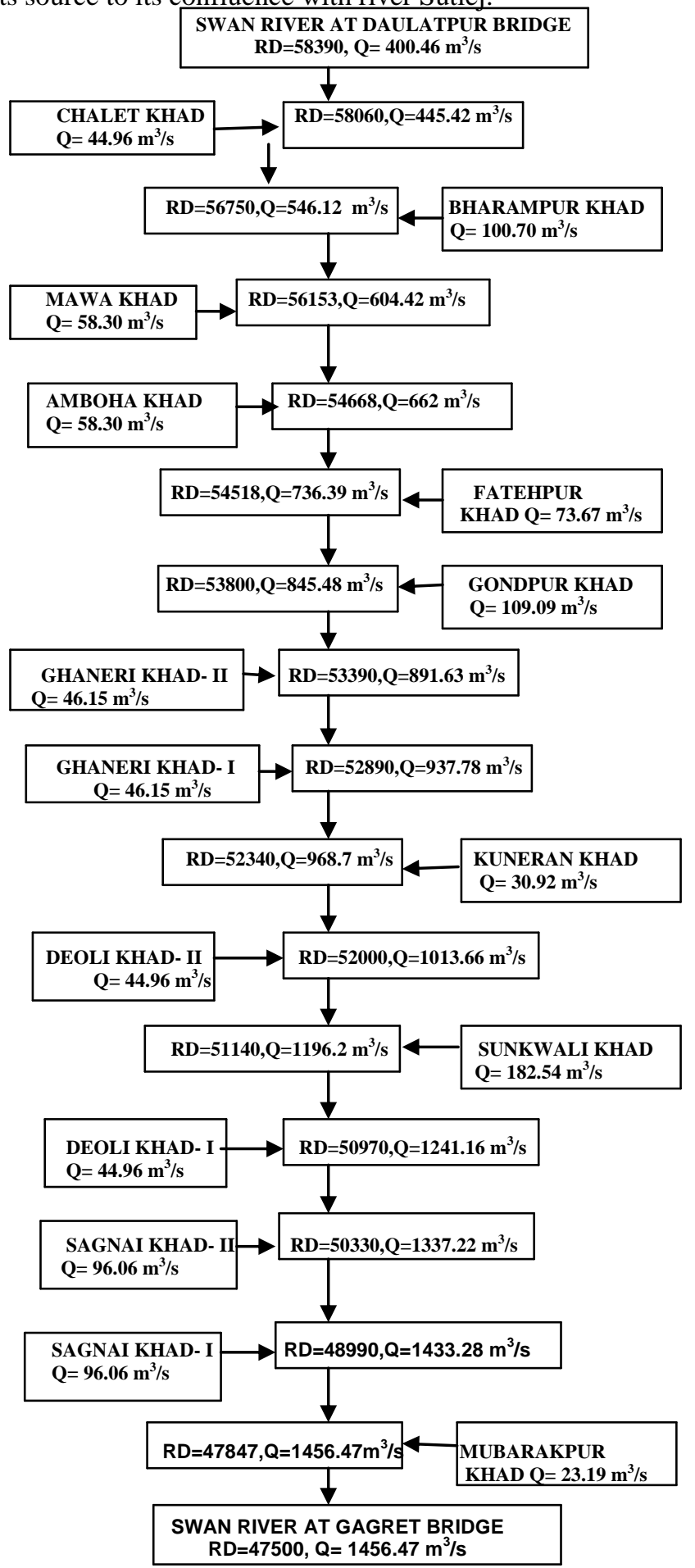

Figure 2: Schematic diagram of River Swan and its tributaries
The formers nearby Swan River are practicing agriculture on both the banks. During flood season, the agricultural lands nearby river are heavily damaged by floods. Every year farmers are facing severe problem and losing their crops. In view of this, IPH Department, Government of Himachal Pradesh has decided to provide embankments in the main Swan River as well as tributaries joining the River Swan in that reach. Project authorities approached CWPRS for the suitability of proposed embankment though model studies. Mathematical model studies of River Swan were conducted at CWPRS from Daulatpur bridge to Gagret bridge having a reach length of about $11 \mathrm{~km}$ (Fig. 1). There are about 15 tributaries joining River Swan in this reach.

\section{MATHEMATICAL MODEL STUDIES}

Based on the hydraulic data and river cross section data, 1-D mathematical model (HEC-RAS) studies were carried out to assess the adequacy of the proposed flood embankments considering the 25 years return period flood. Total river reach of $11 \mathrm{~km}$ from Daulatpur bridge to Gagret bridge with its 15 tributaries (Fig. 1) was simulated in the model by using the cross sections of river Swan and its tributaries. The cumulative discharges of River Swan as shown in schematic diagram (Figure. 2) from the starting reach to end reach are reproduced in the model.

Table 1. Comparison of water levels predicted by HECRAS model with water levels supplied by project authorities

\begin{tabular}{|c|c|c|c|c|}
\hline $\begin{array}{l}\text { SL. } \\
\text { No }\end{array}$ & Location & $\begin{array}{c}\text { Discharge } \\
\text { in } \mathrm{m}^{3} / \mathrm{s}\end{array}$ & $\begin{array}{c}\text { Water level } \\
\text { supplied by } \\
\text { Project } \\
\text { Authority }\end{array}$ & $\begin{array}{c}\text { Water level } \\
\text { computed by } \\
\text { using } \\
\text { HECRAS }\end{array}$ \\
\hline 1. & $\begin{array}{l}\text { U/S of } \\
\text { Daulatpur } \\
\text { bridge }\end{array}$ & 400.46 & 499.45 & 499.50 \\
\hline 2. & $\begin{array}{l}\mathrm{D} / \mathrm{S} \text { of } \\
\text { Gagret } \\
\text { bridge }\end{array}$ & 1456.47 & 456.34 & 456.31 \\
\hline
\end{tabular}

Model studies were first carried out for existing condition (without embankments) for the discharge of 25 years return period flood. The mathematical model was run by varying the manning's ' $n$ ' and the value of ' $n$ ' for which the water level matched well with the measured gauge data was selected for the further studies. The observed gauge discharge data at upstream of Daulatpur bridge and downstream of Gagret bridge were used for proving studies. It was found that the predicted water levels at Daulatpur bridge and Gagret bridge were more or less in agreement with the levels observed by the project authority with a manning's ' $n$ ' value of 0.037 as shown in Table 1 . In view of this, the model was considered as proved with the manning's $n$ value of 0.037 . 


\section{STUDIES WITH EMBANKMENT}

The cross sections with embankments of River Swan and its tributaries as proposed by project authority were reproduced on the mathematical model. The cumulative discharges of the River Swan as shown in schematic diagram (Figure 2) from the starting reach to end reach are reproduced in the model. Simulations were carried out for the above mentioned discharges and the velocity of flow, depth of flow, discharge intensity and water levels were computed at various locations. Similar simulations and computations were carried out for the tributaries also with manning's $n$ value equal to 0.045 . Longitudinal water surface profile, velocity and discharge intensity of River Swan with and without embankment from Daulatpur bridge to Gagret bridge are shown in Figure 3, 4 and 5 respectively.

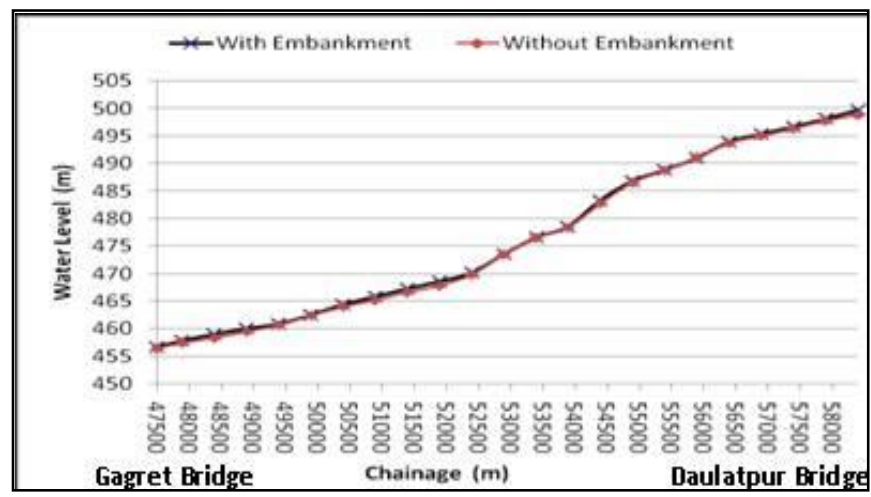

Figure 3: Longitudinal water surface profile of river Swan from Daulatpur bridge to Gagret bridge

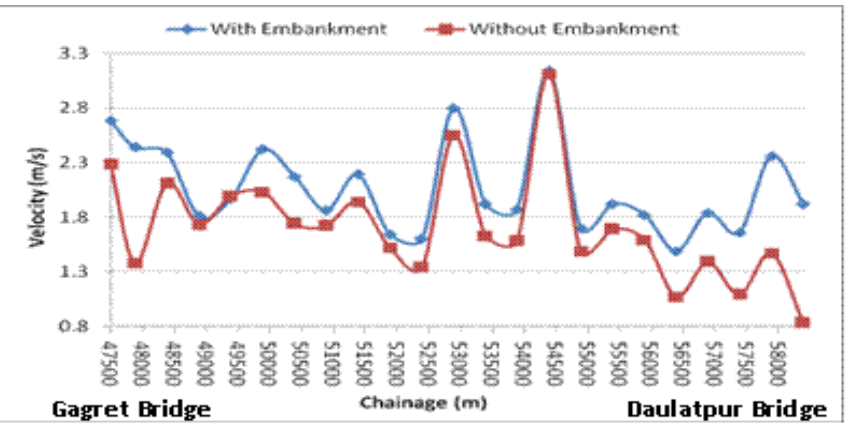

Figure 4: velocity profile of river Swan with and without embankments from Daulatpur bridge to Gagret bridge

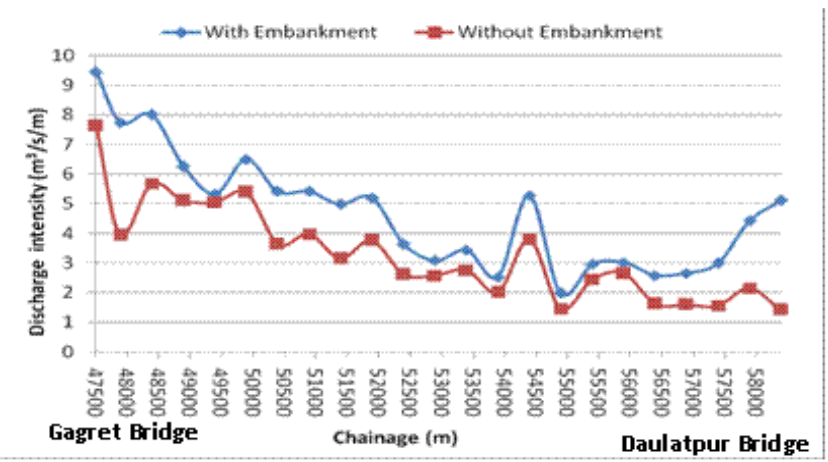

Figure 5: Discharge intensity of river Swan with and without embankments from Daulatpur bridge to Gagret bridge
It was observed that the maximum velocity of $3.14 \mathrm{~m} / \mathrm{s}$ and maximum discharge intensity of $9.43 \mathrm{~m}^{3} / \mathrm{s} / \mathrm{m}$ is expected in River Swan. The velocities and discharge intensities varied from $0.23 \mathrm{~m} / \mathrm{s}$ to $2.65 \mathrm{~m} / \mathrm{s}$ and $0.36 \mathrm{~m}^{3} / \mathrm{s} / \mathrm{m}$ to $3.66 \mathrm{~m}^{3} / \mathrm{s} / \mathrm{m}$ in tributaries. The increased velocities and discharge intensities would possibly induce higher scour near the toe and erosion of the embankments. In view of this it is suggested to protect the embankments by providing proper bank protection works and launching apron at the toe as shown in figure 6.

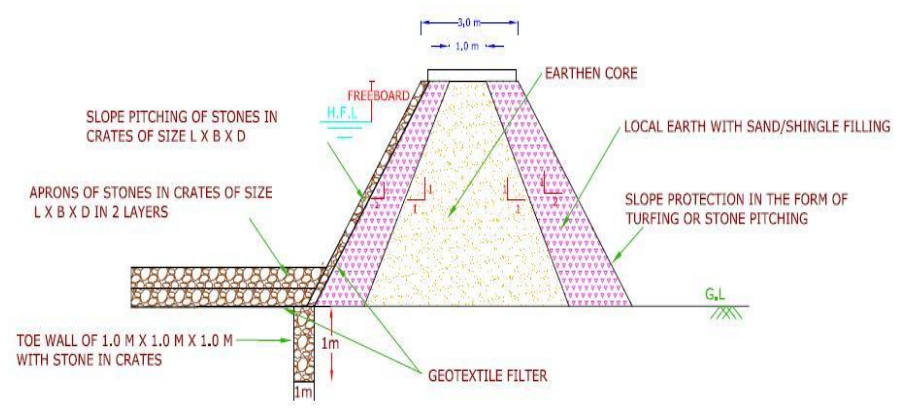

Figure 6: A typical cross section of embankment for tributaries

\section{CONCLUSIONS}

On the basis of river cross sections, hydrologic data of river, one-dimensional mathematical model (HEC-RAS) was carried out to estimate the flood level in the river for discharge of 25 years return period. Based on the above studies, following conclusions were made :

1. It is recommended that the top level of the embankments of river Swan and tributaries may be finalized by using the maximum water levels obtained during model studies with embankments by adding sufficient free board.

2. The distance between both the embankments (River width) as proposed by project authorities at each cross sections of river Swan and its tributaries are sufficient.

3. It is recommended to align the embankments such that the meanders of the river are within the embankments and the width covers the Thalweg of the river.

4. The top width of the embankment, may be kept as $6.0 \mathrm{~m}$ in main swan river and $3.0 \mathrm{~m}$ in its tributaries.

5. It is recommended to provide slope pitching in the form of stones in crates of size $1.5 \mathrm{~m} \times 1.5 \mathrm{~m} \times 0.3$ $\mathrm{m}$ up to about at least $1.5 \mathrm{~m}$ above the expected HFL for River Swan and its tributaries.

6. It is recommended to provide $6 \mathrm{~m}$ wide launching apron for River Swan. The launching apron would consist of two layers of stones in crate of size 1.5 $\mathrm{m} \times 1.5 \mathrm{~m} \times 0.3 \mathrm{~m}$ laid over geofabric filter.

7. It is recommended to provide $3 \mathrm{~m}$ wide launching apron for the tributaries. The launching apron would consist of two layers of stones in crate of size $1.5 \mathrm{~m} \times 1.5 \mathrm{~m} \times 0.3 \mathrm{~m}$ laid over geofabric filter. 
8. To avoid damage to the geofabric filter during placement of stones in crates, a $15 \mathrm{~cm}$ thick layer of coarse sand or gravel should be provided over the geofabric filter.

\section{ACKNOWLEDGEMENTS}

We wish to express our deep sense of gratitude to Shri. S. Govindan, Director, CWPRS for constant encouragement and valuable suggestions during the course of this studies and kind permission given for publishing this paper.

\section{REFERENCES}

[1]. Garde. R. J., 2006 "River Morphology", New Age International Publishers, 2006

[2]. M. N. Singh, B. Raghuram Singh, and S. S. Kerimani., "Prediction of water levels for evolving suitable flood protection measures" International conference on Hydraulics and Water Resours HYDRO 2013, pp. 803-806, 2013

[3]. Neena Isaac, Mehendale P. B. and Shitole M. S., "River Training in Alluvial Flood Plains", Conference on Hydraulics and Water ResourcesHYDRO 2003, pp. 198-204, 2003.

[4]. Publication No.60, "Manual on River Behaviour, Control and Training", 1971.

[5]. Ranga Raju, K.G., Garde, R. J. and Yadav, H. S., "Modelling Bed Level Variations in Alluvial Streams". ISH Journal, Vol.2, pp. 28-43, 1996

[6]. Sharma D. D., 2006 "Floods and Flash Floods in Himachal Pradesh: A Geographical Analysis"

[7]. Technical Report No.4999 of CWPRS, "Mathematical model studies for proposed flood protection measures from Daulatpur bridge to Gagret bridge along river Swan”. September 2012.

[8]. Yung Hai Chen, Abbas A. Fiuzat, Benjamin R. Roberts., " Salt River channelization project model study" Journal of Hydraulics Engineering, Vol.111, pp. 267-283 